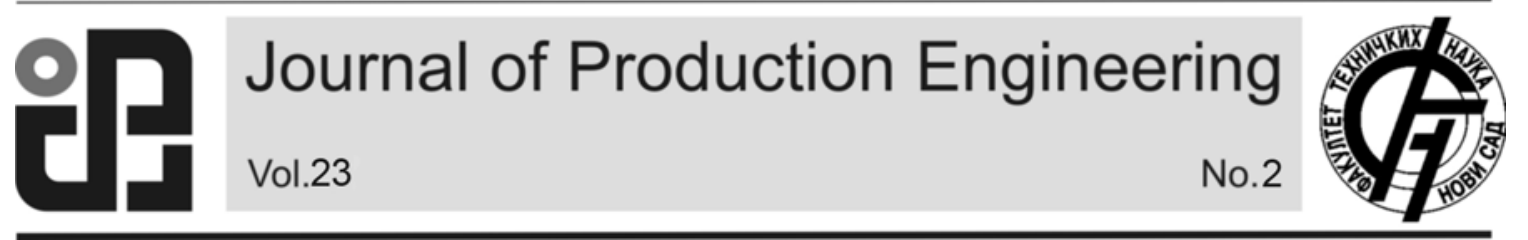

JPE (2020) Vol.23 (2)

Peko, I., Nedić, B., Dunđer, M., Samardžić, I.

Original Scientific Paper

\title{
TAGUCHI OPTIMIZATION OF BEVEL ANGLE IN PLASMA JET CUTTING PROCESS OF ALUMINIUM ALLOY 5083
}

Received: 14 September 2020 / Accepted: 29 November 2020

\begin{abstract}
This paper presents Taguchi optimization of bevel angle in plasma jet cutting process of aluminium alloy EN AW 5083. Experimentations for this paper were carried out on the basis of standard $L_{27}$ Taguchi's orthogonal array in which three plasma jet cutting parameters such as cutting speed, arc current and cutting height were arranged at three levels. From the analysis of means, analysis of variance and two-way interactions plot, significant plasma jet cutting process parameters and optimal combination of their levels that lead to minimal bevel angle were identified. The results showed that all three process parameters significantly affect bevel angle response. The predicted response at optimal plasma jet cutting conditions has a good fit with result of bevel angle from observed experiment.
\end{abstract}

Key words: Taguchi optimization, bevel angle, plasma jet cutting, aluminium.

Taguchi optimizacija ugla nagiba kod procesa rezanja mlazom plazme aluminijske legure 5083. Ovaj rad prezentira Taguchi optimizaciju uglaa nagiba kod procesa rezanja mlazom plazme aluminjske legure EN AW 5083. Experimenti za ovaj rad su sprovedeni na temelju standardnog $L_{27}$ Taguchi otogonalnog plana gde su tri parametra procesa rezanja mlazom plazme: brzina rezanja, jačina struje i debljina rezanja podešeni na tri nivoa. Iz analize srednjih vrednosti, analize varijance i prikaza dvosmernih interakcija identifikovani su značajni parametri procesa rezanja mlazom plazme i optimalna kombinacija njihovih nivoa koja dovodi do minimalnog ugla nagiba. Predviđeni odziv u optimalnim uslovima rezanja mlazom plazme se dobro poklapa s rezultatom ugla nagiba iz izvedenog eksperimenta.

Ključne reči: Taguchi optimizacija, kut nagiba, rezanje plazmenim mlazom, aluminijum.

\section{INTRODUCTION}

Plasma jet cutting process is nonconventional manufacturing process that is very present today in metal and shipbuilding industry. This process uses energy of highly ionized gas in order to generate high temperature plasma jet that can be used to cut different materials at various thicknesses. Cut quality is the main cutting process response that is defined by characteristics such as kerf width, bevel angle, surface roughness, dross height, material removal rate and heat affected zone. It is desirable to set process parameters values in order to achive optimal cut quality. These process parameters are mostly cutting speed, arc current, cutting height and gas pressure. These parameters are usually defined by machine operator and they significantly affect cut quality characteristics. Many authors conducted scientific researches in order to describe influences of variable plasma jet cutting process parameters on cut quality responses and to define their optimal values. The most of these researches were conducted on steel materials [1-9].

Aluminium is as material softer and more conductive than steel. According to that there exists some kind of insecurity in cutting of aluminium by plasma jet. In spite of that it can be cut by plasma jet and it is possible to define procees parameters values that lead to optimal cut quality characteristics. A few papers investigate influence of high temperature plasma jet on cut quality of aluminium. Common material in these papers is aluminium alloy 5083. Aluminium alloy 5083 is quite present in shipbuilding industry where aluminium plates are mostly cut by plasma jet before welding and assembling in ship sections. Due to that it is very important to identify optimal plasma jet cutting conditions in order to minimize further postprocessing operations. Peko et al. [10] described an influence of cutting speed and arc current on surface roughness of cut. They conducted mathematical modeling of surface roughness using artificial neural network approach. Experimental results were obtained according to Taguchi $\mathrm{L}_{9}$ orthogonal array. Generated mathematical model was used to create surface plot and to define process parameters values that minimize surface roughness. Peko et al.[11] analyzed influence of cutting speed, arc current and cutting height on kerf width response. Experiments were conducted using Taguchi $\mathrm{L}_{18}$ orthogonal array. Using experimental data a feedforward backpropagation artificial neural network model was developed. Mathematical model was verified using Mean Square Error (MSE) between experimental and predicted data of kerf width. Verified model was used to generate 2D and 3D plots that show effects of process parameters on kerf width values and to define cutting areas that result with minimal kerf widths. Peko et al. [12] conducted research of the heat affected zone occurred in material during plasma jet cutting process. Heat affected zone analysis was done by measuring hardness changes on the material cross sections and by microscopic observations of the material structure. 
Variable process parameters whose effects were analyzed in the research are cutting speed and arc current.

It is obvious that there exists an open space for further scientific investigations in plasma jet cutting process of aluminium alloys. It is possible to apply different methods and techniques in order to mathematically describe an influences of variable process parameters on cut quality responses and to define optimal cutting conditions. These findings can be very useful for further cutting process improvements.

This paper applies Taguchi method for identification of optimal plasma jet cutting parameters which minimize bevel angle as main cut quality response. Procees parameters whose effects were analyzed are cutting speed, arc current and cutting height.

\section{EXPERIMENTAL PROCEDURE}

Experiments were performed on aluminium sheet $\mathrm{Al}$ 5083, thickness $3 \mathrm{~mm}$. CNC machine that was used for cutting was FlameCut 2513 (Fig. 1.). Experimental plan was defined according to Taguchi $\mathrm{L}_{27}$ othogonal array where three process parameters: cutting speed $(v)$, arc current $(I)$ and cutting height $(H)$ were varying on three levels. These levels are listed in Table 1. Constant proccess parameters during experimentations were: outlet nozzle diameter: $1.2 \mathrm{~mm}$, plasma gas: compressed air, plasma gas pressure: 6 bar. In each experimental trial straight cut length $80 \mathrm{~mm}$ was made.

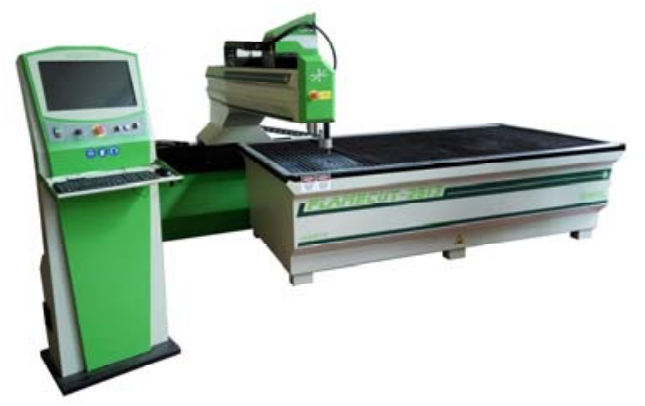

Fig. 1. CNC plasma jet cutting machine FlameCut 2513

\begin{tabular}{|l|c|c|c|c|}
\hline \multirow{2}{*}{$\begin{array}{l}\text { Cutting } \\
\text { parameter }\end{array}$} & Unit & \multicolumn{3}{|c|}{ Level } \\
\cline { 3 - 5 } & 1 & 2 & 3 \\
\hline $\begin{array}{l}\text { Cutting } \\
\text { speed, } v\end{array}$ & $\mathrm{~mm} / \mathrm{min}$ & 2000 & 4000 & 6000 \\
\hline $\begin{array}{l}\text { Arc } \\
\text { current, } I\end{array}$ & A & 45 & 65 & 85 \\
\hline $\begin{array}{l}\text { Cutting } \\
\text { height, } H\end{array}$ & $\mathrm{~mm}$ & 1 & 1.5 & 2 \\
\hline
\end{tabular}

Table 1. Plasma jet cutting parameters and their levels

Bevel angle was choosen as output cut quality response. It is one of the most important cut quality responses in plasma jet cutting process because it defines geometrical accuracy of produced parts. Bevel angle $(\alpha)$ was calculated using the following formula:

$$
\alpha(\circ)=\left|\tan ^{-1}\left(\frac{W_{t}-W_{b}}{2 s}\right)\right|
$$

where $s$ is sheet thickness, $W t$ and $W b$ are top and bottom kerf widths. Top and bottom kerf widths were measured using universal optical microscope on three equally distanced places along the length of the cut. The average bevel angle values for each experimental trial are listed in Table 2 .

\begin{tabular}{|c|c|c|c|c|}
\hline $\begin{array}{c}\text { Exp. } \\
\text { trial }\end{array}$ & $\begin{array}{c}v \\
(\mathrm{~mm} / \mathrm{min})\end{array}$ & $I(\mathrm{~A})$ & $H(\mathrm{~mm})$ & $\alpha\left(^{\circ}\right)$ \\
\hline 1 & 2000 & 45 & 1 & 7.782 \\
\hline 2 & 2000 & 45 & 1.5 & 6.993 \\
\hline 3 & 2000 & 45 & 2 & 6.013 \\
\hline 4 & 2000 & 65 & 1 & 3.805 \\
\hline 5 & 2000 & 65 & 1.5 & 4.745 \\
\hline 6 & 2000 & 65 & 2 & 2.252 \\
\hline 7 & 2000 & 85 & 1 & 3.367 \\
\hline 8 & 2000 & 85 & 1.5 & 3.633 \\
\hline 9 & 2000 & 85 & 2 & 1.327 \\
\hline 10 & 4000 & 45 & 1 & 9.044 \\
\hline 11 & 4000 & 45 & 1.5 & 9.722 \\
\hline 12 & 4000 & 45 & 2 & 8.876 \\
\hline 13 & 4000 & 65 & 1 & 5.313 \\
\hline 14 & 4000 & 65 & 1.5 & 5.048 \\
\hline 15 & 4000 & 65 & 2 & 5.682 \\
\hline 16 & 4000 & 85 & 1 & 2.891 \\
\hline 17 & 4000 & 85 & 1.5 & 3.272 \\
\hline 18 & 4000 & 85 & 2 & 2.796 \\
\hline 19 & 6000 & 45 & 1 & 11.539 \\
\hline 20 & 6000 & 45 & 1.5 & 12.662 \\
\hline 21 & 6000 & 45 & 2 & 10.444 \\
\hline 22 & 6000 & 65 & 1 & 8.643 \\
\hline 23 & 6000 & 65 & 1.5 & 9.648 \\
\hline 24 & 6000 & 65 & 2 & 9.360 \\
\hline 25 & 6000 & 85 & 1 & 7.360 \\
\hline 26 & 6000 & 85 & 1.5 & 8.428 \\
\hline 27 & 6000 & 85 & 2 & 7.360 \\
\hline
\end{tabular}

Table 2. Plasma jet cutting experimental plan and bevel angle results

In Table 3 are given an examples of bevel angles (blue lines) that appear on cuts depending on different process parameters values.

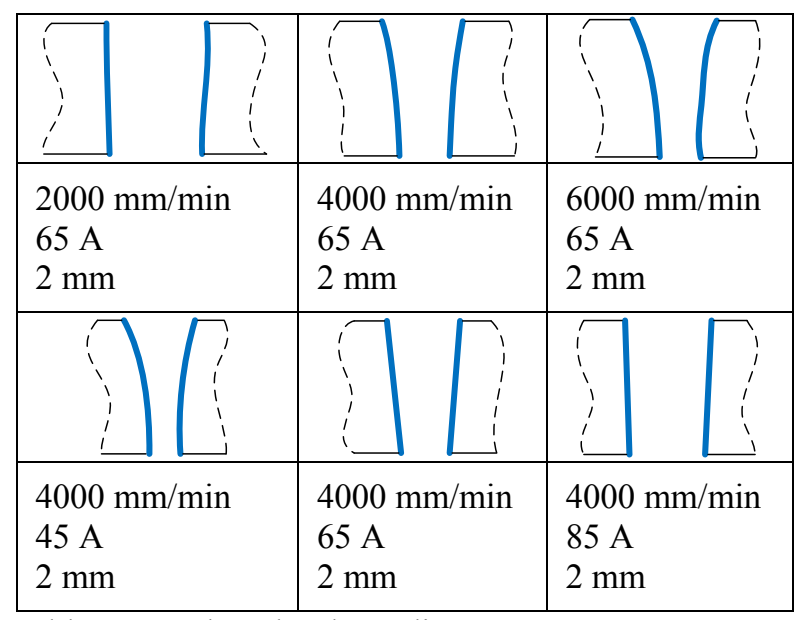

Table 3. Bevel angles depending on process parameters values 


\section{TAGUCHI OPTIMIZATION}

Taguchi methodology is a powerful tool for product/process quality improvement. This methodology is used for efficient identification of near optimal settings of the control parameters making the product/process insensitive to the noise factors $[13,14]$. Two major tools used in the Taguchi method are orthogonal arrays (OAs) and signal to noise $(\mathrm{S} / \mathrm{N})$ ratio $[13,14]$. Taguchi found out empirically that $\mathrm{S} / \mathrm{N}$ ratios give the (near) optimal combination of the parameters levels, where the variance is minimal, while keeping the mean close to the target value, without using any kind of model $[13,15]$.

\subsection{Determining the optimal levels of the plasma jet cutting parameters}

Taguchi method was used to identify the near optimal plasma jet cutting process parameters that result with minimal bevel angle values. In plasma jet cutting process, the lower bevel angle values are desirable in order to reach high cut quality, therefore smaller-thebetter $\mathrm{S} / \mathrm{N}$ ratio can be calculated as:

$$
S / N=\eta=-10 \log \left(\frac{1}{n} \sum_{i=1}^{n} y_{i}^{2}\right)
$$

where $y_{i}$ is $i$ th observed value of the response, $n$ is number of observations in a trial.

Calculated $\mathrm{S} / \mathrm{N}$ values are given in Table 4.

The bevel angle experimental results and its corresponding $\mathrm{S} / \mathrm{N}$ values were analyzed using the analysis of means (ANOM) and analysis of variance (ANOVA) with the MINITAB statistical software.

The ANOM response graph for the main effects of the plasma jet cutting parameters on mean $\mathrm{S} / \mathrm{N}$ ratio for the bevel angle is presented in Figure 2. As shown in Figure 2 all three cutting parameters significantly affect the formation of bevel angle in the plasma jet cutting process. Cutting speed $(v)$ and arc current $(I)$ have the most significant influence on the bevel angle whereas the influence of the cutting height $(H)$ is little bit smaller. As seen, the optimal plasma jet cutting condition for minmizing bevel angle is $v: 2000 \mathrm{~mm} / \mathrm{min}$, I: $85 \mathrm{~A}$ and $H: 2 \mathrm{~mm}$.

To more precisely identify the optimal process parameters levels the interactions effects plot (Fig. 3) and ANOVA analysis were generated (Table 5). From these results it is revealed that interactions $v^{*} I$ and $v^{*} H$ are the most influential on the bevel angle response. Figure 4. presents contour interaction $v^{*} I$ effect plot on $\mathrm{S} / \mathrm{N}$ values of bevel angle. It is obvious from interaction effect plot that previously defined optimal cutting condition can be confirmed (Table 6).

\begin{tabular}{|c|c|c|c|l|}
\hline $\begin{array}{c}\text { Exp. } \\
\text { trial }\end{array}$ & $\begin{array}{c}v \\
(\mathrm{~mm} / \mathrm{min})\end{array}$ & $I(\mathrm{~A})$ & $H(\mathrm{~mm})$ & $\begin{array}{c}\mathrm{S} / \mathrm{N} \\
(\mathrm{dB})\end{array}$ \\
\hline 1 & 2000 & 45 & 1 & -17.822 \\
\hline 2 & 2000 & 45 & 1.5 & -16.893 \\
\hline 3 & 2000 & 45 & 2 & -15.581 \\
\hline 4 & 2000 & 65 & 1 & -11.606 \\
\hline 5 & 2000 & 65 & 1.5 & -13.524 \\
\hline 6 & 2000 & 65 & 2 & -7.053 \\
\hline 7 & 2000 & 85 & 1 & -10.544 \\
\hline 8 & 2000 & 85 & 1.5 & -11.206 \\
\hline 9 & 2000 & 85 & 2 & -2.458 \\
\hline 10 & 4000 & 45 & 1 & -19.126 \\
\hline 11 & 4000 & 45 & 1.5 & -19.755 \\
\hline 12 & 4000 & 45 & 2 & -18.964 \\
\hline 13 & 4000 & 65 & 1 & -14.507 \\
\hline 14 & 4000 & 65 & 1.5 & -14.062 \\
\hline 15 & 4000 & 65 & 2 & -15.090 \\
\hline 16 & 4000 & 85 & 1 & -9.220 \\
\hline 17 & 4000 & 85 & 1.5 & -10.295 \\
\hline 18 & 4000 & 85 & 2 & -8.929 \\
\hline 19 & 6000 & 45 & 1 & -21.243 \\
\hline 20 & 6000 & 45 & 1.5 & -22.050 \\
\hline 21 & 6000 & 45 & 2 & -20.377 \\
\hline 22 & 6000 & 65 & 1 & -18.733 \\
\hline 23 & 6000 & 65 & 1.5 & -19.688 \\
\hline 24 & 6000 & 65 & 2 & -19.425 \\
\hline 25 & 6000 & 85 & 1 & -17.337 \\
\hline 26 & 6000 & 85 & 1.5 & -18.514 \\
\hline 27 & 6000 & 85 & 2 & -17.337 \\
\hline
\end{tabular}

Table 4. Calculated $S / N$ ratios for each trial

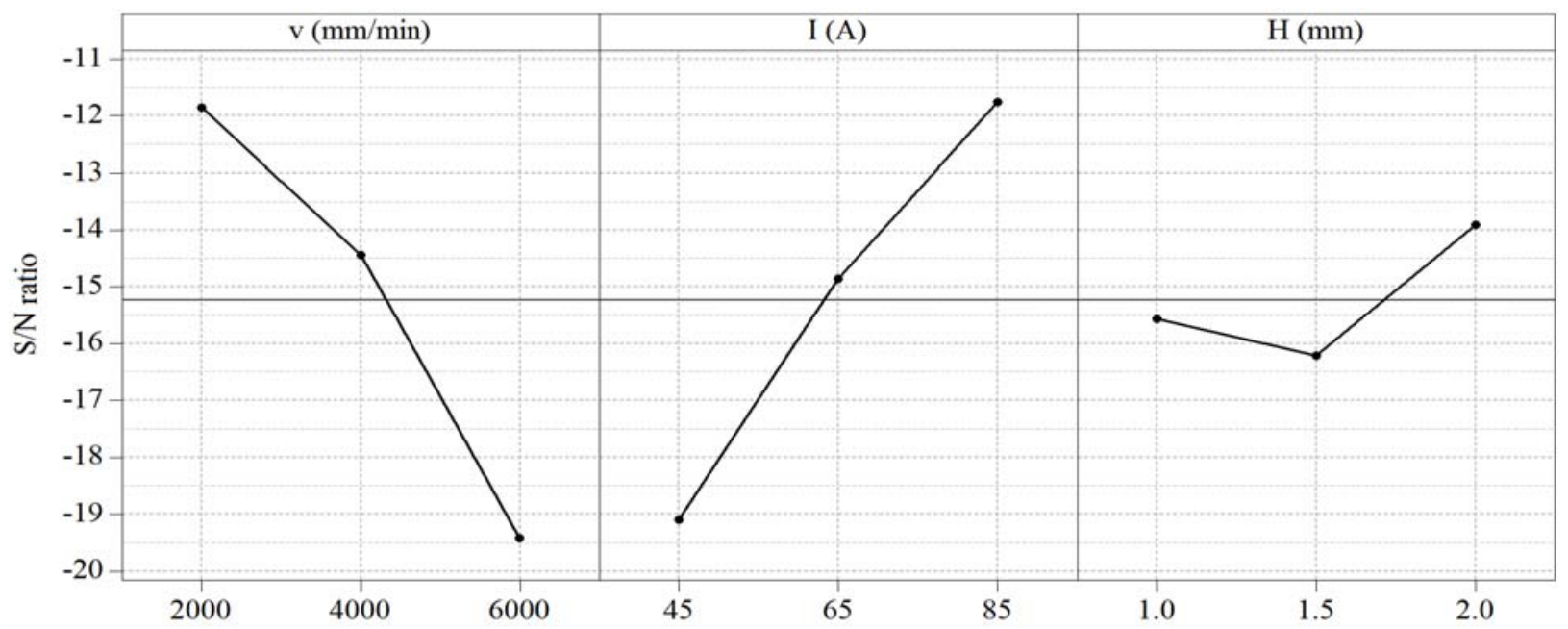

Fig. 2. Main effects plot of the $\mathrm{S} / \mathrm{N}$ ratios for the bevel angle 


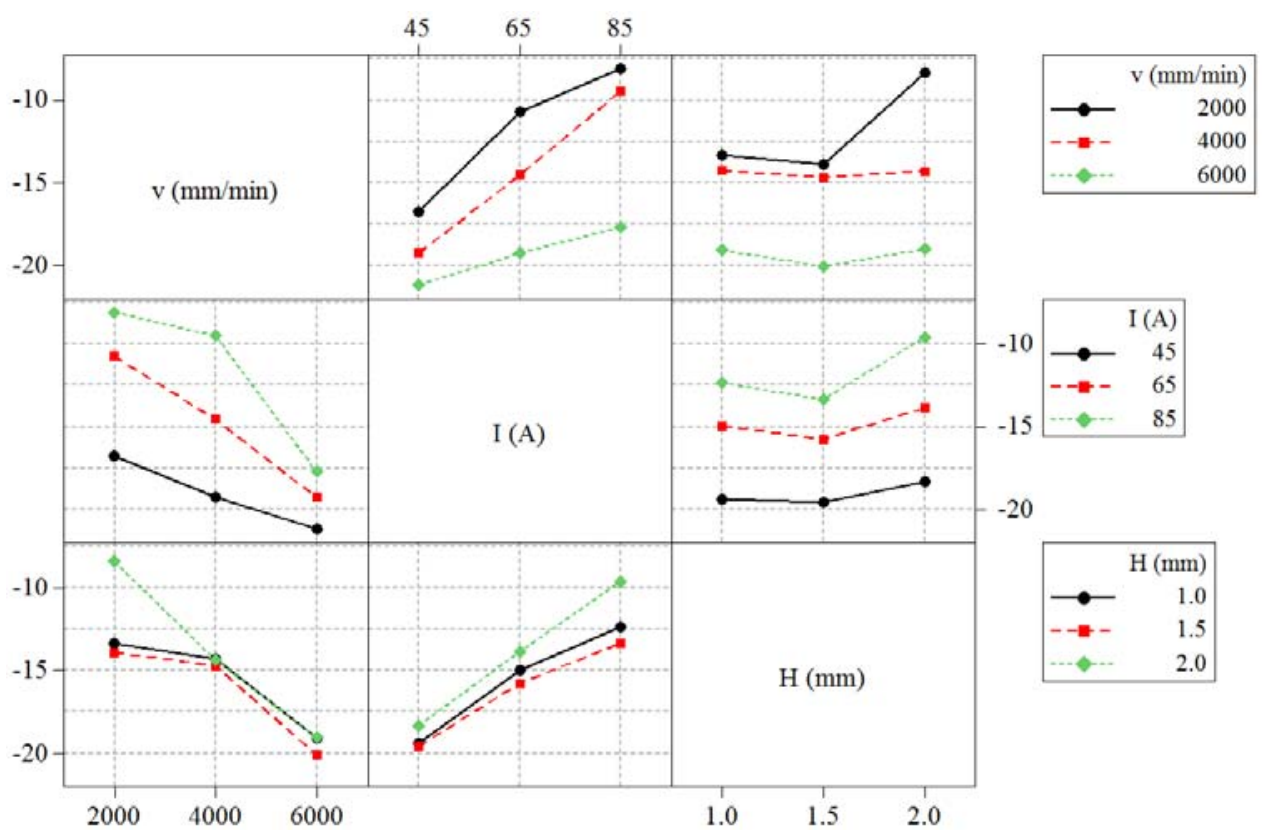

Fig. 3. Interactions effects plot of the average $\mathrm{S} / \mathrm{N}$ ratios for the bevel angle

\begin{tabular}{|c|c|c|c|c|c|c|}
\hline $\begin{array}{l}\text { Source of } \\
\text { variation }\end{array}$ & $\begin{array}{l}\text { Degrees of } \\
\text { freedom } \\
(\mathrm{DOF})\end{array}$ & $\begin{array}{c}\text { Sum of } \\
\text { squares } \\
(\mathrm{SS})\end{array}$ & $\begin{array}{l}\text { Mean square } \\
\text { (MS) }\end{array}$ & $\mathrm{F}$ & $\mathrm{p}$ & $\rho(\%)$ \\
\hline$v$ & 2 & 265.579 & 132.789 & 78.66 & 0.000 & 42.558 \\
\hline$I$ & 2 & 243.737 & 121.869 & 72.19 & 0.000 & 39.058 \\
\hline$H$ & 2 & 25.498 & 12.749 & 7.55 & 0.014 & 4.085 \\
\hline$v^{*} I$ & 4 & 37.913 & 9.478 & 5.61 & 0.019 & 6.075 \\
\hline$v^{*} H$ & 4 & 32.129 & 8.032 & 4.76 & 0.029 & 5.148 \\
\hline$I^{*} H$ & 4 & 5.676 & 1.419 & 0.84 & 0.537 & 0.909 \\
\hline Error & 8 & 13.505 & 1.688 & & & 2.164 \\
\hline Total & 26 & 624.037 & & & & \\
\hline
\end{tabular}

Table 5. Results of ANOVA for $\mathrm{S} / \mathrm{N}$ ratio

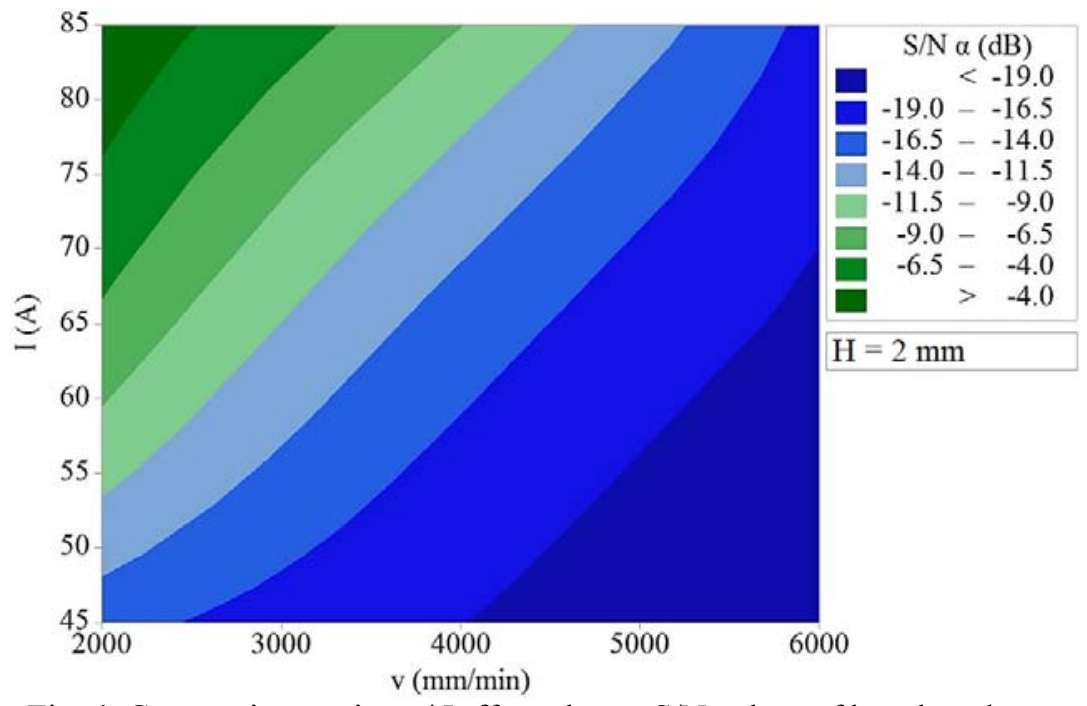

Fig. 4. Contour interaction $v^{*} I$ effect plot on $\mathrm{S} / \mathrm{N}$ values of bevel angle

\begin{tabular}{|l|c|}
\hline Plasma jet cutting parameter & Optimal level \\
\hline Cutting speed, $v(\mathrm{~mm} / \mathrm{min})$ & 2000 \\
\hline Arc current, $I(\mathrm{~A})$ & 85 \\
\hline Cutting height, $H(\mathrm{~mm})$ & 2 \\
\hline
\end{tabular}

Table 6. Optimal plasma jet cutting process conditions for the bevel angle response 


\subsection{Confirmation experiment}

Once the optimal plasma jet cutting conditions are selected, final step in Taguchi optimization methodology is to predict and verify the expected response through the confirmation experiment. However, there is no need to conduct confirmation test if the optimal plasma jet cutting parameters combination is already included in the experimental plan. In this case, since the optimal combination of process parameters (Table 6) corresponds to the 9-th experimental trial, no confirmation experiment was conducted.

Taguchi prediction of $\mathrm{S} / \mathrm{N}$ ratio under optimum conditions $\left(\hat{\eta}_{\text {opt }}\right)$ can be calculated using the following equation [13]:

$$
\hat{\eta}_{o p t}=\bar{\eta}+\sum_{i=1}^{p}\left(\bar{\eta}_{i, o p t}-\bar{\eta}\right)
$$

where is $\bar{\eta}$ total mean $\mathrm{S} / \mathrm{N}$ ratio, $\bar{\eta}_{i, \text { opt }}$ mean $\mathrm{S} / \mathrm{N}$ ratio for $i$-th parameter at the optimal level, $p$ number of parameters that significantly affect the quality characteristic.

In order to statistically judge the closeness of the predicted $\left(\hat{\eta}_{o p t}\right)$ and observed value of $\mathrm{S} / \mathrm{N}$ ratio $\left(\hat{\eta}_{o b s}\right)$, the confidence interval (CI) was determined using equation [16]:

$$
C I=\sqrt{\frac{F_{\alpha(1, f e) \cdot V_{e}}}{n}}
$$

where $F_{\alpha(1, f e)}$ is $F$ value at a confidence level of $(1-\alpha), V_{e}$ error variance, and $n$ is defined as:

$$
n=\frac{N}{1+v}
$$

where $N$ is total number of experiments, $v$ is total degrees of freedom of all parameters.

At the $95 \%$ confidence level, the CI is \pm 2.612 . Since the prediction error is within CI value the optimal combination of plasma jet cutting parameter levels can be validated. These results are given in Table 7 . Bevel angle obtained under optimal cutting conditions is given in Figure 5.

\begin{tabular}{|l|c|}
\hline $\mathrm{S} / \mathrm{N}$ predicted $\left(\hat{\eta}_{\text {opt }}\right), \mathrm{dB}$ & -3.71636 \\
\hline $\mathrm{S} / \mathrm{N}$ observed $\left(\hat{\eta}_{\text {obs }}\right), \mathrm{dB}$ & -2.45817 \\
\hline Prediction error, dB & 1.25819 \\
\hline $\mathrm{CI}, \mathrm{dB}$ & \pm 2.612 \\
\hline
\end{tabular}

Table 7. Validation of optimal process parameters levels for minimization of bevel angle
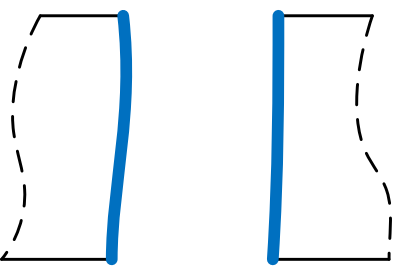

Fig. 5. Bevel angle obtained with optimal process parameters values $(v: 2000 \mathrm{~mm} / \mathrm{min}, I: 85 \mathrm{~A}, H$ : $2 \mathrm{~mm}$ )

\section{CONCLUSION}

This paper presented application of Taguchi optimization methodology for minimization of bevel angle in plasma jet cutting process of aluminium alloy 5083. Experimentations were conducted on sheet thickness $3 \mathrm{~mm}$ according to Taguchi $\mathrm{L}_{27}$ orthogonal array. From conducted experimental research and derived analysis next conclusions are made:

- All three process parameters significantly affect bevel angle response in plasma jet cutting process.

- Cutting speed and arc current have the highest influence while the cutting height has a smaller influence on the bevel angle as cut quality characteristic.

- ANOVA and two-way interactions plot show that interactions cutting speed-arc current and cutting speed-cutting height are statistically significant.

- Obtained results indicate that cutting speed should be kept at the lowest level, while arc current and cutting height at the highest level in order to reach minimal bevel angle.

- Taguchi method was proven as a quick and efficient way to find optimal plasma jet cutting conditions.

- Lack of Taguchi method is in defining near optimal process parameters values. In order to define precisely optimal process parameters levels that lead to the optimal process response different mathematical modeling and optimization techniques should be applied.

- Complexity of plasma jet cutting process requires taking into account other cut quality characteristics such as kerf width, surface roughness, dross height, material removal rate and conducting multi-objective optimization.

\section{REFERENCES}

[1] Kumar Das, M., Kumar, K., Barman, K.T., Sahu, P.: Optimization of process parameters in plasma arc cutting of EN31 steel based on MRR and multiple roughness characteristics using grey relational analysis, Procedia material science, 5, p.p. $1550-1559,2014$.

[2] Adalarasan, R., Santhanakumar, M., Rajmohan, M.: Application of Grey Taguchi-based response surface methodology (GT-RSM) for optimizing the plasma arc cutting parameters of $304 \mathrm{~L}$ stainless steel, International Journal of Advanced Manufacturing Technology, 78, p.p. 1161-1170, 2015.

[3] Maity, K.P., Kumar Bagal, D.: Effect of process parameters on cut quality of stainless steel of plasma arc cutting using hybrid approach, International Journal of Advanced Manufacturing Technology , 78, p.p. 161-175, 2015.

[4] Srinivasa Raju, S.V.S.S., Kodanda Ram, K., Satyanarayana, D.V.S.S., Sai Nishood Goud, M.: Optimization of Process Parameters of Plasma Arc 
Cutting Using Taguchi's Robust Design Methodology, IOSR Journal of Mechanical and Civil Engineering, International Conference on Recent Innovations in Civil \& Mechanical Engineering, 3, p.p. 124-128, 2016.

[5] Pawar, S.S., Inamdar, K.H.: Experimental Analysis of Plasma Arc Cutting Process for SS 316 L Plates, IOSR Journal Of Mechanical and Civil Engineering, 6th National Conference on "Recent Developments In Mechanical Engineering", 5, p.p. 75-80, 2017.

[6] Radovanović, M., Madić, M.: Modeling the plasma arc cutting process using $A N N$, Nonconventional Technologies Review, 4, p.p. 43-48, 2011.

[7] Tsiolikas, A., Kechagias, J., Salonitis, K., Mastorakis, N.: Optimization of cut surface quality during CNC Plasma Arc Cutting process, International Journal of Systems Applications, Engineering \& Development, 10, p.p. 305-308, 2016.

[8] Nedić, B., Janković, M., Peko, I.: Surface roughness analysis at plasma cutting, Proceedings SERBIATRIB '17, 15th International Conference on Tribology, p.p. 366-370, 2017.

[9] Peko, I., Nedić, B., Đorđević, A., Džunić, D., Janković, M., Veža, I.: Modeling of Surface Roughness in Plasma Jet Cutting Process of Thick Structural Steel, Tribology in Industry, 4, 522-529, 2016.

[10]Peko, I., Nedić, B., Đorđević, A., Đurić, S., Džunić, D., Veža, I., Janković, M.: Prediction of surface roughness in plasma jet cutting process using neural network model, Proceedings SERBIATRIB '17, 15th International Conference on Tribology, p.p. 520-525, 2017.

[11]Peko, I., Nedić, B., Đorđević, A., Veža, I.: Modelling of Kerf Width in Plasma Jet Metal Cutting Process using ANN Approach, Technical Gazette, 25 (2), p.p. 401-406, 2018.
[12]Peko, I., Ljumović, P., Nedić, B., Dunđer, M.: Analysis of the heat affected zone in plasma jet cutting process of the aluminium alloy $E N A W$ 5083, Zastita Materijala, 60 (2), p.p. 174-181, 2019.

[13] Madić, M., Radovanović, M., Gostimirović, M.: Selection of near optimal laser cutting parameters in $\mathrm{CO}_{2}$ laser cutting by the Taguchi method, Transactions of the VŠB-Technical University of Ostrava, Mechanical Series, 59 (2), p.p. 99-107, 2013.

[14]Phadke, M.S.: Quality engineering using robust design, Prentice Hall, New Jersey, p.p. 334, ISBN 0137451679, 1989.

[15] Marinković, V., Madić, M.: Optimization of surface roughness in turning alloy steel by using Taguchi method, Scientific Research and Essays, 6 (16), p.p. 3474-3484, 2011.

[16] Madić, M., Radovanović, M.: Identification of the Robust Conditions for Minimization of the HAZ and Burr in $\mathrm{CO}_{2}$ Laser Cutting, FME Transactions, 41, p.p. 130-137, 2013.

Authors: Ivan Peko PhD, Development Engineer, AD Plastik Group, Matoševa 8, Solin, Croatia

Full Professor Bogdan Nedić PhD, University of Kragujevac, Faculty of Engineering, Sestre Janjić 6, Kragujevac, Serbia

Full Professor Marko Dunđer PhD, University of Rijeka, Study of Polytechnic, Sveučilišna avenija 4, Rijeka, Croatia

Full Professor Ivan Samardžić PhD, Josip Juraj Strossmayer University of Osijek, Mechanical Engineering Faculty in Slavonski Brod, Trg Ivane BrlićMažuranić 2, Slavonski Brod, Croatia

E-mail: ipeko@fesb.hr nedic@,kg.ac.rs marko.dundjer1@gmail.com isamar@sfsb.hr 